\title{
Writing Horrible Words
}

\author{
REBECCA GOWERS
}

\author{
The rationale for producing yet another book on English \\ usage
}

At the 'English Usage (Guides) Symposium', Cambridge 2014, I was invited to account for my revision of Plain Words (Gowers, 2014), the style guide originally written by my great-grandfather, Sir Ernest Gowers (1880-1966). And because, by the time I gave that talk (see Gowers, 2018), I was already writing my own book on the English language, intended as a sort of adjunct to Plain Words, the arguments aired at that Cambridge gathering were particularly interesting to me. That said, they also left me more daunted than ever by my own project.

It would be reasonable to wonder what on earth had prompted me, in a crowded market, to want to turn out yet another amateur title in this subject area. Before starting to labour over Plain Words, I had never read any tomes on usage of the kind written by Simon Heffer, John Humphrys, Neville Gwynn, and the like; and when I did take a look, I was startled and extremely unimpressed both by what they were selling, and by the manner in which they were selling it. Among linguists who have stooped to consider such works, this will be a common experience. For me, the poor impression was exacerbated by discovering that every last one of the guides I happened to flick through had co-opted now-outmoded snippets from my greatgrandfather's work in support of exactly the ossified and snobbish approach to English usage that he himself, in 1954, had been seeking to oppose. Thus, one of the prompts that led me to want to write my own, supplementary book was a desire to challenge their purported linguistic kinship with someone who was my actual, literal forebear. That was not an appropriate fight to conduct explicitly on the pages of Plain Words, though the broad idea is deducible from my preface to the 2014 edition. But it was a fight I thought I might attempt in a book of my own.

Here I might quickly note that the particular writers I am talking about are often referred to, not least by themselves, as 'sticklers'. Given that I had no wish to cede ground to them as authoritative arbiters in the way the label 'stickler' seems to imply, one of my preliminary decisions was that I would refer to them instead as 'gripers', which, without being particularly offensive, seemed like a better fit. And what was it they were griping about? Predominantly it was the rules, as they understood it, of what they deemed to be Correct English - rules often presented by them as virtual truisms. Sadly the word falsism has not become commonplace over the past couple of hundred years. John Stuart Mill, in 1835, credited falsism to Coleridge, explained in definition (b) in the Oxford English Dictionary as, 'A platitude that has not even the merit of being true'. Taking this on board, one of the tasks I set myself in my book was to attempt to persuade any intimidated or compliant reader of thundering works on Correct English that, often, the stickler's truism is much more accurately characterised as the griper's falsism.

A notional 'intimidated reader' is the relevant figure here because, of course, no linguist takes

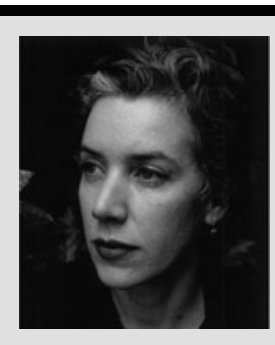

REBECCA GOWERS is the author of The Swamp of Death, shortlisted for a CWA non-fiction Golden Dagger Award, and of two novels, When to Walk and The Twisted Heart, both longlisted for the Orange Prize. She recently revised the style guide Plain Words by her great-grandfather, Sir Ernest Gowers, and wrote a satirical companion volume, Horrible Words. She is currently writing a book about the mysterious character who was murdered by Eadweard Muybridge, to be published in 2019. reb.gowers@gmail.com 
such amateur guides to be authoritative. Indeed, linguists would say, and do say, that the pertinent truism in this context is that much of what is peddled in these backwards-looking books is justified using bogus information and specious logic, and that their authors apply the resulting 'rules' with dramatic lack of consistency. As it is no great challenge to prove this, and the challenge has been met before, was there anything else I wanted to achieve? The answer to that is simple to state, but was not simple to execute. I wanted to write a book that would beguile and unsettle my reader with humour, because, as far as I could see, simply demolishing these arguments with facts did not appear to be having the desired effect.

I shall now violate what I myself hold to be two excellent rules. The first is that you should never explain a joke; the second, that you should never answer your critics.

To break the first rule, I shall try to lay out how I arrived at the precise rationale for my book. My thinking went more or less as follows: we all know that what constitutes fairly formal Standard English changes over time. When enough people adopt a stigmatised word or a derided form of syntax, it can start to become acceptable to those who previously rejected it. Furthermore, the evidence shows that when this happens to a form that is in some way genuinely peculiar or illogical, those who pontificate about correctitude will eventually class the now-acceptable usage under the heading 'charmingly idiomatic'. In thinking about this, I was struck by how, crudely speaking, because linguistic conservatives believe we should automatically abide by retrograde norms, they cede the future of the language to the rule-breakers, allowing those whom they despise to determine very largely what future conservatives will find acceptable. Many rule-breakers are, one assumes, unaware of their role in this process. Indeed, many may barely even be aware of what 'Standard English' is generally taken to mean. But what if they did know? It came to me as a semi-serious point that, if the rulebreakers understood the prevailing conservative conventions and bravely broke with them on purpose, they would then be taking a deliberate (if fractional) hand in shaping how formal Standard English developed. I hoped that my imaginary, timid reader might find this a liberating way to think about contested parts of the language; and this led to my book's subtitle, in which I inverted the subtitle of Plain Words: I decided I would write 'A Guide to the Misuse of English'.
With this in mind, I was cheered to find an oblique model for the contents, a model that gave me the quotations that head the two sections of my book. This was a lecture by the Victorian writer and literary critic Andrew Lang (1844-1912), published in booklet form in 1890. His title was How to Fail in Literature. In what is an extravagant piece of comedy, he notes that most aspiring writers do fail, and argues from this that, apparently 'an education in ill-success, is really a popular want ... it is not enough to attain failure, we should deserve it'. He goes on to give advice that should, he says, make 'disaster almost inevitable' (Lang, 1890: 20), including broad notes on style. Not only does he recommend that his reader should imitate 'invertebrate' novels (Lang, 1890: 57), but for clarity he also supplies inspiration, such as 'the sun sank in "a cauldron of daffodil chaos" (Lang, 1890: 57). $\mathrm{He}$ gives practical advice too, for example: 'A good way of making yourself a dead failure is to go about accusing successful people of plagiarising from books or articles of yours which did not succeed, and, perhaps, were never published at all' (Lang, 1890: 57). Anyone who has dipped into the world of publishing is likely to find Lang as wince-inducingly funny now as he presumably was 127 years ago, but it is a little disappointing, or so I find, that almost at the end of the lecture he loses his nerve, and writes: 'If anyone has kindly attended to this discourse, without desiring to be a failure, he has only to turn the advice outside in' (Lang, 1890: 87). (Parenthetically, I would cite this as a good example of its having been a bad idea to explain a joke.)

By writing 'A Guide to the Misuse of English', I intended to offer my own reader the daft and almost guilty pleasure of encountering what to some would look like terrible advice. And in order, I hoped, to import some of Lang's comic tension into my book, I summoned up a fairly exaggerated idea of my reader as a rule-breaker. However, Lang's project is comparatively uncomplicated, in that he was jokily advocating breaking a set of rules that, in truth, he believed to be thoroughly worth keeping. By way of strong contrast, my underlying aim was to call into question the precise value of the rules I was satirising, making my project rather less straightforward than his. For this reason, though also in the further service of comic tension, I never wavered in pointing out the penalties that might arise from breaking whichever rule I was discussing, given that, in certain circumstances, deviating from old-fashioned Standard English can count against you. 
Despite our crucial differences, it was from Lang that I drew the conceit of advising the person who goes wrong unwittingly on how to go wrong on purpose. The opening section of my book, where I had to manoeuvre my reader into wearing this hat, was undoubtedly one of the hardest parts to write. After suggesting that this carefree person almost certainly, from time to time, made accidental assaults on Correct English, I continued by saying: this being so, "Why carry on in a state of partial ignorance, lobbing pebbles here and there, and being despised in return, when you could be disporting yourself with savage brilliance in the front lines?' (Gowers, 2016: 16). I went on to suggest that the person who deliberately braves the opprobrium of conservative critics while operating on the front edge of language change, inching it forward in the process, will be taking a hit for those more fearful, or indeed unknowing, rulebreakers who follow behind; and I offered to explain how this charitable battle might best be fought.

Of course, couched in these terms, this was, as I say, a humorous proposition. But having dreamt up the idea of my aspirant edifice-smashing reader, then what? I had for some time been idly noting down a list of those words people tend to conspire in saying they hate, either on the grounds that they are horrible in themselves for some reason, say preprepared, or because, though not horrible when used in one way, they supposedly become horrible (and indeed wrong) when used in another, as with decimate. Before long, I saw that my list could be divided into categories and sub-categories - blend words, double negatives, slipslops, monosyllables, and so on - and that these divisions would handily give me 23 short chapters. It was at this point that I decided to go all out and call my book Horrible Words.

The default model for each chapter was to show how, as I mentioned above, the actual arguments given for the horribleness of specific stigmatised words are very often nonsense; and how, even supposing those arguments were valid, they are almost always inconsistently applied. Thus, if it is wrong to use decimate to mean 'destroy more than a tenth part of' because this ignores the word's Latin origin (see for instance Heffer, 2010: 142-3), then why is it absolutely fine for a period of quarantine to last less, or more, than 40 somethings? And if preprepared is ridiculous because it gives the sense of 'pre' twice, why is intermingle OK? And if stressed out should just be stressed because the out is redundant, then why is it a 'modern abomination', as Simon Heffer says (Heffer, 2010: 184), to reduce sorted out to the more compact form sorted? And so on, and so on. When you have someone such as John Humphrys making an assertion as profoundly daft as "verbs can refresh a sentence any time they are needed - but not if they earned their crust as nouns in an earlier life' (Humphrys, 2004: 106), then it is no great challenge to send up the arguments of the gripers.

That is all well and good, but attempting to give my projected timid readers pause for thought by showing them where the arguments of the browbeaters fail to stack up was not enough, as far as I was concerned. Having, I hoped, imparted doubt and even a little militancy to those readers, I decided I would then put them through an unexplained torment. In the final paragraphs of almost all of my chapters, I subject the reader to vocabulary, scrupulously drawn from published sources, that falls some way outside most ideas of Standard English - unusual or new and hair-raising examples of the word-types under discussion: to understand up, to enticize, undoubtlessly, and so on. (I assume it was these extreme chapter endings that caused the otherwise generously approving literary editor of The Times to say that at certain junctures my book was likely to 'raise the blood pressure of even liberal-minded readers' [Millen, 2016: 20].)

Here I should perhaps briefly explain the default style of writing I adopted for the book as a whole. If in a language guide you question the parameters of more or less formal Standard English but do so using a prose style other than formal Standard English, you risk the accusation that you have not fully grasped the beauty of what it is you are apparently rejecting. Yet if you use exemplary formal Standard English to call that standard into question, you risk being called a hypocrite. This sounds like lose-lose; but in my case, I was absolutely not seeking to do down formal Standard English, which I love: I was arguing against the limiting and uncivilised strictures of certain of its notional defenders, whom I do not love. As a result, my starting point - the home from which I ventured forth - was indeed formal Standard English. But all through, I speckled my own best attempt at this standard with words a little below the high water mark of calm formality; and I did this because I knew that each informal word I used would acquire, in its difference, a small charge of humour, or (so I hoped) the charge that arises from making the constructed figure of a book's author seem to the reader confidingly human.

To return to what were, by contrast, the drastically non-Standard final paragraphs of my chapters: I wrote them that way because I wanted to unsettle 
my reader. Having, I hoped, helped this person to see past various prejudices that have attached to certain words and grammatical uses, my own use of what I expected would feel like near intolerable words, without comment on my part, was intended to lead this reader to see that choosing venturesome vocabulary is a matter of discrimination, and that making such choices for oneself can be interesting and valuable. Put another way, I went too far over the line, without explanation, in order that my readers should be forced to weigh up where they themselves thought that line should lie.

When it came to concluding the whole book, I recapped by suggesting that brave readers might like to play their part deliberately in nudging English towards what they considered a promising future; but I kept it modest, and proposed that if there were one or two horrible words they thought they might 'fancy, consider useful' and be 'ready to defend', they could perhaps 'dot them about the place on purpose' (Gowers, 2016: 190).

I shall now break the second excellent rule that I mentioned above by dissecting some of the criticism my book attracted. I feel it would be ungracious not to mention that I had some very kind reviews, but will focus here on two especially heart-sinking responses. One, by Lynne Truss (Truss, 2016: 25), represents a counter-blast from the old guard. The other was an initially cheering piece in the Financial Times by their columnist Michael Skapinker, but this also soon went skidding off the rails (Skapinker, 2016: 9). I fear both can be taken to indicate that the rationale for my book, which I have just attempted to explain, was in fact too complicated.

I have talked all along about a timid reader who turns to English usage guides. The earliest mention of Horrible Words in the press was a tiny prepublication notice in the Irish Times. Under the heading, 'Books to watch out for in 2016', Arminta Wallace had written, 'Finally, we're all guilty: Rebecca Gowers raps us over the knuckles for the misuse of English in Horrible Words' (Wallace, 2016). Reading this, I felt depressed: my title had not been intended to fool humourless extremists into buying a work that they could be expected to hate. After a while, though, I reminded myself that I was not out simply to preach to the converted. Perhaps the opportunity to net trenchantly unsympathetic readers by means of a dangerous subtitle was one to be embraced.

For convenience, let us say that the trenchantly unsympathetic reader can be represented by Lynne Truss, famous for her punctuation manual Eats, Shoots and Leaves (2003). In what I suppose would be classed a 'think piece' in The Times, she tore sarcastically into Horrible Words as 'the latest attack on those awful, unholy "gripers" in our midst ... who dare to lay down the law about English for the general reader, and thereby attract the ire of all those who work on language in an academic capacity' (Truss, 2016: 25) (not that I am an academic). Truss proceeds to quote one or two examples cited in Horrible Words of manifestly outmoded rulings on correctitude, and concedes: 'Obviously all these chaps look ridiculous for taking such stands'. Good enough, except that she then adds: 'But at the same time, ooh, I can't help feeling that someone here is missing the point slightly'. After getting past that playground 'ooh', I was naturally keen to know what point it was that she thought I had slightly missed, and it turned out to be this, or these: 'Isn't reading style guides meant to be a source of entertainment as well as enlightenment? Also, doesn't the reader have the right to disagree?'

I hardly know where to begin in reply, but to take her second point first, I was a reader who disagreed; I exercised the right Truss mentions; Horrible Words was the result.

More importantly, and to return to her first point 'Isn't reading style guides meant to be a source of entertainment as well as enlightenment?' - this sounds perilously as though Truss is saying that you need not worry too much about being right if you are being entertaining. And it therefore also seems perilously close to saying that it is possible to be simultaneously 'enlightening' - her word and 'entertainingly' wrong. Am I being unfair here? Could she really have meant this? Amazingly, the answer seems to be, yes. After all, what virtue does she believe is exemplified by the authors of the usage guides that she is championing? According to Lynne Truss: 'at least they understand what we are crying out for, which is a bit of certainty, for pity's sake' (Truss, 2016: 25).

I do realise that she was taking a humorous tone, by her lights, and that she was going out of her way to portray me as a sort of dismal 'academic' killjoy. Even so, I once again hardly know where to begin with the proposition that we would rather feel bogus certainty than stop to wonder whether we might somehow be off the mark. And on this, let me restrict myself to saying that the area of uncertainty that disturbs her assumed 'us', the front edge of Standard English under pressure of change, is, I would argue, a thought-provoking and often wonderful place. But evidently my attempt to persuade her of this utterly failed. Her one positive comment about the book was that it was 'packed with good 
historical sense'. As for my grip on the present or the future: not so much.

It was a relief to discover, by contrast, that Michael Skapinker, in the Financial Times, had noticed that Horrible Words was, as he put it, 'a call on all English-speakers to ... relish their verbal inventiveness' (Skapinker, 2016: 9). But I was downcast to find that he then asserted that my work contained 'a central contradiction, one common to books that aim to tear down the supposed superiority of ... Standard English: Horrible Words is written entirely in Standard English'.

I have already explained why such a summary was bound to leave me dejected. It is a minor point to say that I did not write 'entirely in Standard English' (Skapinker, 2016: 9), far from it, and that, as detailed above, the very structure of the book was dependent on my not doing so. Leaving that aside, Skapinker was also quite wrong to imply that my aim was to assail what he calls 'the supposed superiority of ... Standard English'. I was arguing about the judiciousness or otherwise of the ways in which supposed Standard English is so-to-speak defended. Furthermore, I was arguing about the legitimacy or otherwise of considering various putatively non-Standard or definitively non-Standard forms inferior. But to raise either of those questions is not, as Skapinker suggests, automatically to devalue, or to attempt to 'tear down', Standard English (or perhaps formal Standard English). I felt actually sad that he had been able to read my book without grasping that, as I mentioned earlier, formal Standard English is a type of English I love, irrespective of the nastiness of some of those who profess to love it as well.

He goes on to remark, as though out-and-out guessing at the contents of my book: 'Instead of simply telling people there is nothing wrong with the way they speak - and there isn't - you could also point out that not everyone sees it that way' (Skapinker, 2016: 9). He adds reproachfully: 'sometimes, to get along in life, it is worth learning powerful people's words too'.

I will avoid, here, going down the byway of asking really who qualifies as powerful these days, with corollary questions about what sort of English props up what sort of power. Instead, I will just say that I fail to see how I could possibly have spelled out more clearly than I did in my book that gripers exist; that they noisily cultivate language prejudice; and that understanding how your choice of words is likely to affect these very people is a competence that might, in certain circumstances, ease your path. I should also add, through gritted teeth, that there would be nothing to stop a frantically timid reader interpreting Horrible Words 'outside in', as Andrew Lang disappointingly puts it, by taking its contents as a compendium of taboos to be observed; that is, as simply a perverse guide to what Skapinker considers 'powerful people's words'.

After talking about the advantages, as he sees it, that come with being fluent in what he labels Standard English, Skapinker adds further, directly accusing me, I suppose: 'It is all very well slumming it with those whose language excludes them from these privileged stockades when you can return to them every night'. I need hardly say that, on the broad scale, this projected divide between slum and stockade is fantastically offensive. Specific to my book, meanwhile, I am distressed by the idea that my project was a complacent exercise in 'slumming it'. The fact that Skapinker was able to progress from talking about a relish for language change to this accusation would seem to indicate that, with him, as with Lynne Truss, the project of my book failed.

As I mentioned above, the 2014 'English Usage (Guides) Symposium' interested me greatly, and this was in part because it laid bare the reciprocal hostility of linguists towards puffed-up language conservatives. Back when I first started thinking about my preface to Plain Words, I was noodling around online one day when I lit upon an interesting passage in a book by Tony Bex and Richard Watts called Standard English: The Widening Debate (1999). In discussing the supposed rules of good English, Bex, in his own article, painted the following picture of my great-grandfather: ' ... we imagine Gowers picking his way delicately through a number of conflicting claims' (Bex, 1999: 102). Those are the words Bex wrote; but the version of his text in front of me had evidently been uploaded using a digital scanner, so what I was surprised to find myself reading was actually this: ' ... we imagine Gowers puking his way delicately through a number of conflicting claims'. I have to say, once I had finished laughing, it struck me that, when it comes to facing down these conflicts, 'delicately puking', even if it is metaphorical, can feel closer to the truth. I know from his letters, held in the family, that my great-grandfather felt extremely uneasy about the anger and disdain that came with his subject. And when Plain Words was published in its first iteration, in 1948, he was duly criticised in parliament and in the press for being too liberal in his views (see Gowers, 2014: xxii). I, too, naturally quaked at the thought of inspiring vitriol, no matter on how relatively small a scale. Nevertheless, I nerved 
myself to conquer any delicate puking that might overcome me, and got on with the job.

As I sat in that sunny conference hall in Cambridge in 2014 listening to some of the ill will swishing around, I went over in my mind one more time the line I hoped to take in Horrible Words. I was not out to make the case: 'You're quite right to express yourself however you generally please, and that's just fine' although for most people, most of the time, that is clearly true. Nor, certainly, was I wanting to say: 'Adhere to these slightly old-fashioned rules, or else' - though, again, in some circumstances it might be an advantage to do so, and a disadvantage not to. What I most wanted to say was more like the following: 'This is how the game is currently being played: if you are interested enough to thumb through books on the subject, let alone to seek advice, do not surrender your natural authority over your own words without stopping to consider how the distribution of power here really works.'

\section{References}

Bex, T. 1999. 'Representations of English in twentieth-century Britain: Fowler, Gowers and Partridge.'
In T. Bex \& R. J. Watts (eds.), Standard English: The Widening Debate. London: Routledge, pp. 89-109.

Gowers, E. 2014. Plain Words: A Guide to the Use of English. (Revised $4^{\text {th }}$ edn.) R. Gowers (ed.). London: Particular Books.

Gowers, R. 2016. Horrible Words: A Guide to the Misuse of English. London: Particular Books.

Gowers, R. 2018. 'Even more complete plain words.' In I. Tieken-Boon van Ostade (ed.), English Usage Guides. History, Advice, Attitudes. Oxford: Oxford University Press, pp. 69-81.

Heffer, S. 2010. Strictly English: The Correct Way to Write ... and Why it Matters. London: Random House.

Humphrys, J. 2004. Lost for Words. London: Hodder \& Stoughton.

Lang, A. 1890. How to Fail in Literature. E. C.: Field \& Tuer.

Millen, R. 2016. 'Words to the wise on how to stress out priceless pedants.' The Times, April 4, 20.

Oxford English Dictionary Online <www.oed.com> (Accessed April 1, 2017).

Skapinker, M. 2016. 'A pedant's progress'. Financial Times, April 9, 9.

Truss, L. 2016. 'A language policeman's lot is not a happy one.' The Times, March 30, 25.

Wallace, A. 2016. 'Books to watch out for in 2016.' Irish Times, January, 2. Online at $<$ https://www.irishtimes.com/ culture/books/books-to-watch-out-for-in-2016-1.2476282> (Accessed April 1, 2017). 